\title{
KNOWLEDGE AND ATTITUDE HAVE NO CORRELATION WITH IMPLEMENTATION OF BREAST SELF EXAMINATION (BSE)
}

\author{
Baksono Winardi, Arini Novianty \\ Midwifery Study Program, Faculty of Medicine, Universitas Airlangga, Surabaya, Indonesia
}

\section{ABSTRACT}

\begin{abstract}
This study aimed to know the existence of relationship between knowledge, attitude and implementation of BSE among midwifery students and mathematics students of Universitas Airlangga. This study used analytic observational method with cross-sectional approach. The sampling technique was the proportional sampling, consisting of 30 students of midwifery and 30 mathematics students. Analysis used was univariat and bivariat analysis with Spearman Rank. The significance level was 0.05 (5\%). This study showed that $90 \%$ of midwifery students had good knowledge of BSE, $66.7 \%$ had sufficient attitude and $46.7 \%$ performed BSE in sufficient category. As many as $66.7 \%$ students of mathematics had sufficient knowledge about BSE, 63.4\% had sufficient attitude and as many as $60 \%$ performed the BSE in the less category. The statistical test revealed $p$ value $=0.267$ for midwife respondents and 0.467 for mathematics respondents. Statistical test on the relationship between BSE attitude and implementation had p=0.100 for midwifery students and 0.407 for mathematics students. As a conclusion, there was no relationship of knowledge, attitude and implementation of BSE in the students of midwife and students of mathematics.
\end{abstract}

Keywords: Knowledge; attitude; implementation; Breast Self Examination (BSE)

\section{ABSTRAK}

Penelitian ini bertujuan untuk mengetahui adanya hubungan pengetahuan dan sikap dengan pelaksanaan SADARI pada mahasiswa pendidikan bidan dan mahasiswa matematika Universitas Airlangga. Metode penelitian ini menggunakan metode observasi analitik dengan pendekatan cross-sectional. Teknik pengambilan sampel yang digunakan adalah proporsi sampling dengan jumlah subjek penelitian 30 mahasiswa pendidikan bidan dan 30 mahasiswa matematika. Analisis yang digunakan adalah analisis univariat dan bivariat dengan uji Spearman Rank dengan taraf signifikasi 0,05 (5\%). Hasil penelitian ini didapatkan 90\% mahasiswa pendidikan bidan memiliki pengetahuan yang baik tentang SADARI, 66.7\% memiliki sikap dalam kategori cukup dan 46,7\% responden melakukan SADARI dalam kategori cukup. 66,7\% siswa matematika memiliki pengetahuan yang cukup tentang SADARI, 63,4\% memiliki sikap dalam kategori cukup dan sebanyak $60 \%$ responden melakukan SADARI dalam kategori kurang. Tidak terdapat hubungan pengetahuan dengan pelaksanaan pada mahasiswa pendidikan bidan $p$ value=0,267 maupun pada mahasiswa matematika, $p=0,467$. Tidak ada hubungan sikap dengan pelaksanaan pada mahasiswa pendidikan bidan, $p=0.100$ maupun mahasiswa matematika, $p=0,407$. Kesimpulan dari penelitian ini adalah tidak ada hubungan pengetahuan dan sikap dengan pelaksanaan SADARI pada mahasiswa bidan dan mahasiswa matematika.

Kata kunci: Pengetahuan; sikap; pelaksanaan; SADARI

Correspondence: Baksono Winardi, Midwifery Study Program, Faculty of Medicine, Universitas Airlangga, Surabaya, Indonesia. Phone: (031) 5020251, 5030252 ext 1161. E-mail: bidan@fk.unair.ac.id

\footnotetext{
pISSN:2355-8393 • eISSN: 2599-056x • doi: http://dx.doi.org/10.20473/fmi.v54i3.10018

- Fol Med Indones. 2018;54:218-221 • Received 31 Jan $2018 \bullet$ Accepted 19 Jul 2018

- Open access under CC-BY-NC-SA license • Available at https://e-journal.unair.ac.id/FMI/
}

\section{INTRODUCTION}

Breast self-examination (BSE) is one of the early detection to observe breast cancer and will be more effective if it is done as early as possible when women reach the reproductive age (Suryaningsih 2009). According to Globocan (2015), the incidence of breast tumors in the United States is found at the age of 20-30 years in \pm 256 patients. In Indonesia, the age of 20-30 years is the age of the students (Audrina 2014). From these data, it is apparent that students need to be more concerned about the health of the breast, especially how to do BSE properly and correctly.

Breast self-examination (BSE) is very beneficial for women. BSE can detect breast abnormalities as early as possible. Whereas, the earlier the discovery of breast cancer, the higher the healing rate or life expectancy of the patients (Ekanita \& Khosidah 2013). BSE is an easy and important breast examination as the first step in 
finding breast cancer (Erbil \& Bolukbas 2012). Good and proper knowledge about BSE will make women care about the breast health. It also can motivate women of childbearing age to routinely perform breast selfexamination so that the possibility of breast cancer can be avoided or resolved as early as possible. This good knowledge will elicit a response or attitude towards BSE. The establishment of this positive attitude will encourage the formation of a good behavior, in this case is the implementation of BSE (Kocher \& Ertem 2012).

Preliminary study conducted on midwifery students found that 9 out of 10 students knew about BSE and 6 students who did it routinely. In mathematics students, from 10 students only 4 knew BSE and only 2 performed the BSE. Midwifery students have an important role as role models and have an obligation to disseminate information about BSE. Whereas, in mathematics students, the information about BSE was less recognized due to the absence of curriculum regarding breast self examination and breast cancer in lectures. This study aimed to determine the relationship between knowledge and attitudes with BSE in midwifery students and mathematics students of Universitas Airlangga.

\section{MATERIALS AND METHODS}

This was an observational cross-sectional study. Population were midwifery and mathematics students in Semester 6, Universitas Airlangga. The sites of the study were Campus A Faculty of Medicine and Campus C Faculty of Science and Technology, Universitas Airlangga. Sampling technique was simple random sampling. The data collection is to explain the purpose of the research to the respondent then give the informed concent sheet. Respondents who are willing to sign a statement are willing to informed concent in sheet and then given a questionnaire (Mubarak 2007). Data analysis in this study used Spearman Rank test with 5\% significance level to know the existence of relationship of knowledge and attitude with the implementation of BSE among midwifery students and mathematics students Universitas Airlangga.

\section{RESULTS}

Table 1 shows that 6 respondents of midwifery students (20\%) have good knowledge about BSE by doing BSE implementation well, 14 respondents $(46.7 \%)$ have good knowledge of BSE with adequate BSE implementation, and 7 respondents $(23.3 \%)$ have good knowledge about BSE with less BSE implementation.

The results of the above analysis also showed that there is 1 respondents having sufficient level of knowledge about BSE with adequate BSE implementation, and $6.7 \%$ of respondents had sufficient level of knowledge about BSE with less BSE implementation. Spearman rank test showed that there was no correlation between knowledge and implementation of BSE on midwifery students, $\mathrm{p}=0.267$.

Table 2 shows that as many as 3 respondents of mathematics students $(10 \%)$ have a good level of knowledge about BSE with the implementation of BSE in average category, as many as 10 respondents (16.7\%) have good knowledge of BSE with BSE implementation category less. The results of the above analysis also indicated that there were 10 respondents had sufficient level of knowledge about BSE with adequate BSE implementation, and $33.3 \%$ of respondents had sufficient level of knowledge about BSE with less implementation. In addition, there were 2 respondents who had knowledge and less implementation of BSE. There was no correlation between knowledge and implementation of BSE among mathematics students, $\mathrm{p}=0.467$.

Table 3 shows that as many as 3 respondents of midwifery students $(10 \%)$ have good attitude level about BSE and well perform of BSE implementation. As many as 4 respondents $(13.4 \%)$ had good attitude of BSE with average implementation of BSE, and as many as 4 respondents $(13.2 \%)$ had good attitude about BSE with less implementation of BSE. Spearman rank test showed no relationship between attitude and BSE implementation among midwifery students, $\mathrm{p}=0.100$.

Table 1. The relationship between knowledge and implementation of BSE among midwifery students

\begin{tabular}{|c|c|c|c|c|c|c|c|c|c|}
\hline \multirow{3}{*}{$\begin{array}{l}\text { Criteria of } \\
\text { Knowledge }\end{array}$} & \multicolumn{6}{|c|}{ Implementation } & \multicolumn{3}{|c|}{ Total } \\
\hline & \multicolumn{2}{|c|}{ Good } & \multicolumn{2}{|c|}{ Average } & \multicolumn{2}{|c|}{ Less } & \multirow{2}{*}{$\mathrm{f}$} & \multirow{2}{*}{$\%$} & \multirow{2}{*}{$P$ value } \\
\hline & $\mathrm{F}$ & $\%$ & $\mathrm{~F}$ & $\%$ & $\mathrm{~F}$ & $\%$ & & & \\
\hline Good & 6 & 20 & 14 & 46.7 & 7 & 23.3 & 27 & 90 & \multirow{4}{*}{0.267} \\
\hline Average & 0 & 0 & 1 & 3.3 & 2 & 6.7 & 3 & 10 & \\
\hline Less & 0 & 0 & 0 & 0 & 0 & 0 & 0 & 0 & \\
\hline Total & 6 & 20 & 15 & 50 & 9 & 30 & 30 & 100 & \\
\hline
\end{tabular}


Table 2. The relationship between knowledge and implementation of BSE among mathematics students

\begin{tabular}{|c|c|c|c|c|c|c|c|c|c|}
\hline \multirow{3}{*}{$\begin{array}{l}\text { Criteria of } \\
\text { Knowledge }\end{array}$} & \multicolumn{6}{|c|}{ Implementation } & \multicolumn{3}{|c|}{ Total } \\
\hline & \multicolumn{2}{|c|}{ Good } & \multicolumn{2}{|c|}{ Average } & \multicolumn{2}{|c|}{ Less } & \multirow{2}{*}{ f } & \multirow[b]{2}{*}{$\%$} & \multirow[b]{2}{*}{$P$ value } \\
\hline & $\mathrm{F}$ & $\%$ & $\mathrm{~F}$ & $\%$ & $\mathrm{~F}$ & $\%$ & & & \\
\hline Good & 0 & 0 & 3 & 10 & 5 & 16.5 & 8 & 26.7 & \multirow{4}{*}{0.467} \\
\hline Average & 0 & 0 & 10 & 33.3 & 10 & 33.3 & 20 & 66.7 & \\
\hline Less & 0 & 0 & 0 & 0 & 2 & 6.7 & 2 & 6.7 & \\
\hline Total & 0 & 0 & 13 & 50 & 17 & 56.7 & 30 & 100 & \\
\hline
\end{tabular}

Table 3. The relationship between attitude and implementation of BSE among midwifery students

\begin{tabular}{|c|c|c|c|c|c|c|c|c|c|}
\hline \multirow{3}{*}{$\begin{array}{l}\text { Criteria of } \\
\text { Attitude }\end{array}$} & \multicolumn{6}{|c|}{ Implementation } & \multicolumn{3}{|c|}{ Total } \\
\hline & \multicolumn{2}{|c|}{ Good } & \multicolumn{2}{|c|}{ Average } & \multicolumn{2}{|c|}{ Less } & \multirow{2}{*}{$\mathrm{f}$} & \multirow[b]{2}{*}{$\%$} & \multirow{2}{*}{$\mathrm{P}$ value } \\
\hline & $\mathrm{F}$ & $\%$ & $\mathrm{~F}$ & $\%$ & $\mathrm{~F}$ & $\%$ & & & \\
\hline Good & 3 & 10 & 4 & 13.4 & 4 & 13.2 & 11 & 36.6 & \multirow{4}{*}{0.467} \\
\hline Average & 3 & 10 & 11 & 36.6 & 5 & 16.8 & 19 & 63.4 & \\
\hline Less & 0 & 0 & 0 & 0 & 0 & 0 & 2 & 0 & \\
\hline Total & 6 & 20 & 15 & 50 & 9 & 30 & 30 & 100 & \\
\hline
\end{tabular}

Table 4. The relationship between attitude and implementation of BSE among mathematics students

\begin{tabular}{|c|c|c|c|c|c|c|c|c|c|}
\hline \multirow{3}{*}{$\begin{array}{c}\text { Criteria of } \\
\text { Attitude }\end{array}$} & \multicolumn{6}{|c|}{ Implementation } & \multicolumn{3}{|c|}{ Total } \\
\hline & \multicolumn{2}{|c|}{ Good } & \multicolumn{2}{|c|}{ Average } & \multicolumn{2}{|c|}{ Less } & \multirow{2}{*}{$\mathrm{f}$} & \multirow{2}{*}{$\%$} & \multirow{2}{*}{$P$ value } \\
\hline & $\mathrm{F}$ & $\%$ & $\mathrm{~F}$ & $\%$ & $\mathrm{~F}$ & $\%$ & & & \\
\hline Good & 0 & 0 & 11 & 36.7 & 16 & 53.3 & 27 & 90 & \multirow{4}{*}{0.407} \\
\hline Average & 0 & 0 & 2 & 6.7 & 1 & 3.3 & 3 & 10 & \\
\hline Less & 0 & 0 & 0 & 0 & 0 & 6.7 & 2 & 6.7 & \\
\hline Total & 0 & 0 & 13 & 43.4 & 17 & 56.6 & 30 & 100 & \\
\hline
\end{tabular}

Table 4 shows that as many as 11 respondents of mathematics students $(36.7 \%)$ have a good attitude level about BSE and doing BSE implementation with average category. As many as 16 respondents (53.3\%) had a good attitude of BSE with less BSE implementation. A total of 2 respondents $(6.7 \%)$ had sufficient attitudes about BSE with sufficient BSE implementation and 1 respondent with attitude in the average category with less implementation of BSE. There was no correlation between attitude with the implementation of BSE among mathematics students, $\mathrm{p}=0.407$.

\section{DISCUSSION}

Based on the results, there was no tendency of higher knowledge about BSE and the better the implementation of BSE. This did not show that the better a person's knowledge, the better the implementation or behavior of the person. There are several factors that cause this. One of them is the attitude of respondents about BSE and also the motivation to do BSE. This is in line with research conducted by Baswedan and Listiowati (2014) that there is no significant relationship between knowledge about breast self-examination and breast tumor with BSE behavior $(\mathrm{p}=0.680)$ with weak correlation. In addition, there are similarities with previous research conducted by Utami (2007) who found the $\mathrm{p}$ value of 0.176 with significance level of $0.064(\mathrm{P}>0.05)$, indicating that there was no significant relationship between knowledge level of breast cancer with breast self-examination behavior (BSE) with very weak correlation level. The results of this study differed from those of the research conducted by Nugraheni (2010) that shows the level of knowledge BSE and behavior BSE among female students DIV Midwifery UNS had significant results with moderate correlation.

Differences between the results of analysis may be due to the attitude of the study subjects to different BSE. In the previous study, $17 \%$ of the total respondents were lazy to do breast self-examination, whereas in this study $60 \%$ of respondents were lazy to do BSE. In addition, in previous study support or motivation to perform BSE from the closest person was very high $(78.3 \%)$, whereas in this study only $13 \%$ of respondents obtained motivation or support from closest persons.

The result of the same study was also found in the respondents of mathematics students who showed no 
correlation between knowledge and implementation of BSE with $p$ value of $0.476(p<0,05)$. The difference in the results of this study with previous one was due to various factors. The first was the subjects of the previous research were health students while in this study the subjects were non-health students. Besides, in the study conducted by Nugraheni (2010) $78.5 \%$ of respondents were not ashamed to do BSE, but in this study $40 \%$ of the respondents felt ashamed to do breast self-examination, and $20 \%$ of respondents felt uncomfortable doing BSE because it has to hold the breast, which were felt as uncomfortable or funny for the respondents.

Respondents already had good response or attitude towards BSE. This can be seen from the respondent's statement that almost $100 \%$ cared about breast health and were interested to implement BSE. Meanwhile, there was an attitude that impeded the implementation of BSE: the fear and the feeling of uncomfortability. As many as 8 respondents still had fear to think about breast cancer so they choose to avoid BSE. In addition, there are 12 respondents who felt funny or uncomfortable to do BSE. Attitudes of these respondents led to the less implementation of the BSE.

\section{CONCLUSION}

High knowledge is not always related to the behavior of a person where in this study the behavior in question is the implementation of BSE. The attitude of a person greatly influences the implementation of BSE. The existence of a good response from individuals will form a good behavior as well. The greatness of one's laziness still overcame his/her high knowledge. However, motivation or support from the closest person is also a factor that influences behavior. Respondent's attitude of shame and uncomfortability also become inhibiting factor of BSE.

\section{REFERENCES}

Audrina GW (2014). Faktor-Faktor yang mempengaruhi tingkat keberhasilan pemberian kemoterapi pada pasien penderita kanker payudara di RSUD Dr. Soetomo dengan menggunakan regresi logistik ordinal. Jurnal Sains dan Seni Pomits 3

Baswedan RH, Listiowati E (2014). Hubungan tingkat pengetahuan tentang Pemeriksaan Payudara Sendiri (SADARI) dengan perilaku SADARI pada mahasiswi non kesehatan di Universitas Muhammadiyah Yogyakarta. Biomedika 6, 1-6

Ekanita P, Khosidah A (2013). Hubungan antara pegetahuan dan sikap WUS terhadap perilaku pemeriksaan payudara sendiri (SADARI). Jurnal Ilmiah Kebidanan 4, 167-177

Erbil N, Bolukbas N (2012). Beliefs, attitudes, and behavior of Turkish women about breast cancer and breast self-examination according to a Turkish version of the champion health belief model scale. Asian Pacific Journal of Cancer Prevention 13, 5823-5828

Kocher A, Ertem G (2012). Breast self examination among nurses and midwife in odemis health districs in Turkey. Proquest. Indiaan Journal of Cancer

Mubarak WI (2007). Promosi kesehatan. Yogjakarta, Graha ilmu

Nugraheni A (2010). Hubungan tingkat pengetahuan tentang SADARI dengan perilaku SADARI sebagai deteksi dini kanker payudara pada mahasiswi DIV Kebidanan FK UNS. Unpublished Applied Science Paper. Surakarta, Faculty of Medicine, Universitas Negri Sebelas Maret

Utami N (2007). Hubungan tingkat pengetahuan kanker payudara dengan perilaku pemeriksaan payudara sendiri (sadari) pada mahasiswi PSIK A FK UGM. Unpublished thesis. Yogyakarta, FK UGM 